Short Communication

\section{EFFECTS OF CHANGE IN BODY WEIGHT \\ ON SERUM AMINOTRANSFERASE AND GAMMA-GLUTAMYL TRANSFERASE LEVELS}

$$
\begin{gathered}
\text { 体重変動の血清アミノトランスフェラーゼ值 } \\
\text { およびガンマグルタミルトランス } \\
\text { フェラーゼ値に及注す影響 }
\end{gathered}
$$

Key words: body weight; aspartate aminotransferase; alanin aminotransferase; gamna-glutamyl transferase; drinking habit

It has not yet been elucidated how body weight changes in daily life can influence the results of hepatobiliary function tests among apparently healthy individuals. Therefore, attempt was made to clarify the statistical relationship of yearly changes in body weight to yearly changes in hepatobiliary function represented by serum aspartate aminotransferase (AST), alanin aminotransferase (ALT) and gamma-glutamyl transferase (GGT) levels on the basis of one-year longitudinal data obtained from health examinations of male workers belonging to a company.

Subjects and methods. The subjects of the present study are male workers of a company which is located in Sagamihara, Kanagawa Prefecture, Japan and produces various kinds of chemical engineering products including magnetic disks and adhesive tapes. Periodic health examinations are conducted on all the workers between September and October every year. The data obtained from health examinations conducted in 1985 and in 1986 were used as study materials. Thus, the data of 663 males who were examined in the two examinations were available for the study. At the health examination conducted in 1985 , the mean and standard deviation of age of the 663 subjects was 36.6 and 8.4 , respectively. In these two examinations, general physical examination, measurement of height, weight and blood pressure, urine tests and biochemical tests for blood specimen including quantification of serum AST, ALT and GGT were conducted. Moreover, in these examinations, drinking habit of each examinee was ascertained through a uniform interview. In the analysis, drinking habits were categorized into "non- or occasional drinking (less than three times per week)" and "habitual drinking (three times or more per week)" according to the results of the interview.

In this study, the magnitude of yearly change in an individual's data for each item between 1985 and 1986 was defined as delta $(\Delta)$ value of the item. The relationship between $\Delta$ value of body weight and $\Delta$ values of AST, ALT and GGT levels in serum was analyzed.

There were three habitual drinkers who had abstained from habitual drinking during the period between the two health examinations. Another eight persons had changed drinking habit from "non- or occasional drinking" to "habitual drinking" during the period. After excluding these 11 persons, the levels of yearly changes in serum AST, ALT and GGT values of the remaining 652 subjects were compared between subgroups classified by age at the health examinations in 1985, drinking habit and the level of yearly change in body weight. Here, the differences in the distribution of $\Delta$ value of serum AST, ALT and GGT levels between the two different subgroups were tested using ridit analysis.1)

Results and discussion. In more than half of the subjects body weight and serum ALT and GGT levels increased during about one-year interval (Table 1). Serum AST level was not the case. These results show that body weight is more closely associated with serum ALT and GGT levels than with serum AST level. However, it is very difficult to evaluate precisely the magnitude of these yearly changes because the comparability between the data from 1985 and those from 1986 may be unreliable. The crosssectional data in Table 2 demonstrates serum ALT and GGT levels are positively associated with $\mathrm{BMI}^{22}$ independent of age and drinking habit. Positive association with drinking was clearly observed only in serum GGT level among these three transferases.

The findings of Fig. 1 show that change in body weight is also closely related to change in hepatobiliary function anong apparently healthy individuals. It appears that increase in body weight can lead to increase in serum AST level as well as serum ALT and GGT levels. In AST and ALT, a positive association with change in body weight was conspicuous especially in non- 
Table 1. Medians, 25 percentiles and 75 percentiles of BMI and serum AST, ALT and GGT levels at the health examination in 1985 and changes ( 4 ) in those levels during about one year in 663 subjects.

\begin{tabular}{|c|c|c|c|c|c|c|c|}
\hline & $35 x$ & uedian & $15 x$ & & 258 & nedian & $75 x$ \\
\hline BM! & 20.7 & 22.1 & 23.8 & $\Delta v e$ Ighe $\left(K_{g}\right)$ & -0.5 & 0.5 & 1.5 \\
\hline$A S T(\mid D / 1)$ & 20 & 24 & 29 & $\Delta \operatorname{AST}(S U / 1)$ & -7 & -3 & 1 \\
\hline ALT $\{(U / 1)$ & 13 & 18 & 27 & $\Delta$ ALT(IU/L) & -3 & 2 & B \\
\hline $\operatorname{sict}(10 / 1)$ & 17 & 24 & 39 & $\Delta \operatorname{GGT}(1 \cup / 1)$ & -3 & 2 & 6 \\
\hline
\end{tabular}

Table 2. Serum AST, ALT and GGT levels according to age, BMI and drinking history.

\begin{tabular}{|c|c|c|c|c|c|c|c|c|c|c|c|c|}
\hline \multirow{4}{*}{$\frac{\text { Ago }}{\text { dýl }}$} & \multicolumn{6}{|c|}{-39} & \multicolumn{6}{|c|}{ 40- } \\
\hline & \multicolumn{2}{|c|}{$-<20$} & \multicolumn{2}{|c|}{$20 \leq-<25$} & \multicolumn{2}{|c|}{$25 \leq-$} & \multicolumn{2}{|c|}{-620} & \multicolumn{2}{|c|}{$20 \leq-<25$} & \multicolumn{2}{|c|}{$25 \leq-$} \\
\hline & No & 0 & SD & D & No & D & ND & D & ND & D & HD & \\
\hline & 56 & 38 & 142 & 154 & 20 & 21 & 6 & 22 & 57 & 111 & 16 & 20 \\
\hline $\operatorname{AST}([\mathrm{U} / \mathrm{l})$ & 21 & 17 & 22 & 24 & 27 & 30 & 27 & 22 & 24 & 26 & 28 & \\
\hline ALT $(I U / 1)$ & 15 & 17 & 10 & 18 & 37 & 31 & 17 & 15 & 20 & 20 & 29 & 30 \\
\hline $\operatorname{Got}(1 \mathrm{U} / 1)$ & 17 & 22 & 20 & 29 & 28 & 37 & 19 & 20 & 23 & 30 & 29 & 56 \\
\hline
\end{tabular}

Medions are listed, ND: Non- or occasional drinkers $D$ : Habilual drinkers Age: Age at tho health exainations in 1935.

or occasional drinkers, while change in serum GGT level was clearly associated with change in body weight especially among habitual drinkers aged 39 or less. The difference in the effects of body weight change on the results of hepatobiliary function tests between non- or occasional drinkers and habitual drinkers may be due to the difference in background of weight change between the two groups. For example, it can be assumed that among habitual drinkers, alcohol intake may play a major role in increase in body weight. Kondo et al. $^{8)}$ have shown in an epidemiological study of a male worker population that drinking may be more important as a cause for increase in serum GGT level than increased body weight. On the other hand, it was observed in our previous study4) that habitual drinking scarcely affects serum AST and ALT levels, whereas these aminotransferase levels are positively associated with obesity index only among non-drinkers. Therefore, the effects of change in body weight on hepatobiliary function may depend on the concition of alcohol intake or nutritional background which brings about change in body weight. However, the findings of this study also demonstrated that any levels of serum AST, ALT or GGT can be elevated by
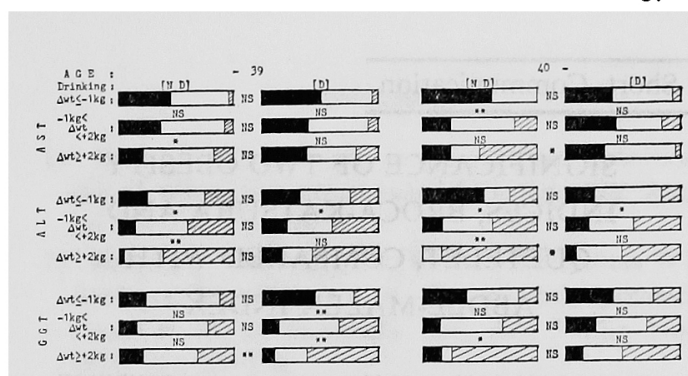

Fig. 1. Relations of changes in body weight to changes in hepatobiliary function indicators by age and drinking habit. [HD]: non- or occasional drinkers, [D]: habitual drinkers, $\Delta \mathrm{wt}$ : $\Delta$ weight, AGE: age at baseline. Relative frequencies are given by the proportions of areas of the following three columns: $(\triangle \mathrm{AST}, \triangle \mathrm{ALT}, \Delta \mathrm{GGT}) \leq$ $-5 \mathrm{IU} / l, \square:-5 \mathrm{IU} / l<(\Delta \mathrm{AST}, \Delta \mathrm{ALT}, \Delta \mathrm{GGT})$ $<+5 \mathrm{IU} / l$, WIAs: $(\Delta \mathrm{AST}, \triangle \mathrm{ALT}, \Delta \mathrm{GGT}) \geq+5$ IU/l. Statistical significance of the difference in changes in hepatobiliary function indicators between above and below groups or between left and right groups: ${ }^{* *} p<0.01,{ }^{*} p<0.05$ (by two-tailed, both), NS: not significant at the 0.05 level.

increase in body weight irrespective of drinking habit. It is concluded from the results of this study that body weight control is essential for the primary prevention of hepatobiliary function disorders.

\section{References}

1) Bross IDJ. How to use ridit analysis. Biometrika $1958 ; 14: 18-38$.

2) Keys A, Fidanza F, Karvonen MJ, et al. Indices of relative weight and obesity. J Chron Dis 1972; 25: 329-343.

3) Kondo H, Hashida M, Momotani H. Serum gamma-glutamyl transpeptidase as a diagnostic aid in the periodic health examination. Jpn J Ind Health 1976; 19: 95-101.

4) Takashima Y, Furukawa T. Effects of overweight and habitual drinking on serum transaminase levels. Keio J Med 1984; 33: 1-16.

Yutaka TAKashmMa, Takashi AkAmatsu, Yasuhide ORIDO, Takaaki KINOUE

Department of Public Health, Kyorin University School of Medicine, 6-20-2Shinkawa, Mitaka, 181 Japan

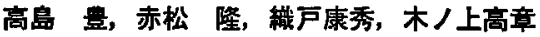

杏林大学医学部公䀽衛生学教室

Received for publication, February 6, 1992

Reprint requests to $\mathrm{Y}$. Takashima, 通信先：高島むて 